\title{
Elements of Hate in the Formation of the Brazilian Society
}

\author{
Thiago Anastácio Carcará* \\ Doctor of Constitutional Law, State University of Piauí, Brazil
}

Submission: May 28, 2019; Published: June 13, 2019

*Corresponding author: Thiago Anastácio Carcará, Doctor of Constitutional Law, State University of Piauí, Av. Raul Lopes, no. 880, room 1107, Teresina-PI, Brazil

Abstract

The construction of Brazilian society occurred in the midst of a cultural miscegenation that enabled titles such as racial democracy, however, this imaginary band of full equality and peaceful coexistence fostered the formation of provisional judgments that, not properly refuted, forged prejudices and stereotypes, the basis of hate speech. Understanding such elements of hatred will enable a better understanding of Brazilian society and an understanding of the existing social frictions. For this, a historical incursion was made, with a temporal range delimited to the relevant episodes within the context outlined, observing its social repercussions on the current composition of Brazilian society.

Keywords: Elements of hate; Brazilian society; Racial democracy; Hate speech

\section{Introduction}

The historical dimension of the demarcated theme refers to the roots by which odious movements were formed. The construction of a society is shaped by values delineated by history, being indispensable to perquiri them. For the purposes intended in this research, the history of Brazilian society from the colonial period to the twenty-first century is the temporal delimitation, and the facts that sediment the creation of groups and embody the discourse of hatred will be the points addressed. It should not be forgotten that by the very nature of the birth of Brazilian society, it will be necessary to enter into distant elements, but related to the points to be addressed. The sociological matrices of the Brazilian people "[...] are shaped as variants of the Lusitanian version of the Western European civilizational tradition, differentiated by color inherited from the American Indians and African Negroes" [1]. The miscegenation of so many cultures provided Brazilian society with a vast diversity of social groups, which formed around characteristics peculiar to its matrix. In the year 1500, when the Portuguese arrived, the territory corresponding to Brazil was composed of one million Indians, organized in tribes and villages, each counting from 300 to two thousand inhabitants, which at the time of discovery was equivalent to the population of Portugal.

The Lusitanians, entering American soil, imposed the civilizing and classist spirit, extending the reach of the Catholic Church and the Holy Office, introducing the scientific knowledge acquired for centuries, initiating a process of civilization of the Indians, as well as colonizing the previously unknown territory. The entrance of the slaves, coming mainly from the west coast of the African continent, in fact, little influenced the cell originating from the social matrix of the Brazilian people. The cultural contribution of the Negro was little relevant in the formation of that original protocell of Brazilian culture. Invigorated to increase sugar production, it would comprise the fundamental contingent of the labor force. Although his role as a cultural agent was more passive than active, the Negro was of crucial importance, both because of his presence and the working mass that produced almost everything done here, and because of his sly but tenacious and continuous introduction that highlighted the Brazilian racial and cultural amalgamation with its strongest colors [1].

The formation of the indigenous population in tribes was similar to that of African blacks, both possessing different languages, cultures, and modes. This cultural miscegenation, strengthened and commanded by the Lusitanians, emerged with the cultural formation of the Brazilian people in all its ethnic diversity. The self-identification of the individual as a Brazilian has covered a sufficient time span for the complete miscegenation between the different ethnicities existing in the territory, not only physical but intellectual, in which the cultural formation determined how the Brazilian people will behave. 


\section{The ideological Roots of Brazil}

The formation of Brazilian society contains its ideological roots founded on Indians, Negroes and Lusitanians. Their values intertwine, overlap each other, or remain intact. The history itself determined the conformation of these social elements, and some values continue to be opposed to others, leading to the emergence of cultural conflicts. The finding of conflicting matrices in Brazilian society results in the evidence of historical aspects that endure for the time without any value change, persisting dogmas in the cultural evolution of the country. Blacks and Indians were seen as obstacles to the civilizing process. In order to solve this problem, biological and moral miscegenation was bet- ter. Representative of this point of view is the thought of Silvio Romero, who postulated a scale or ranking of races, where the lowest was represented by the Indians, followed by the blacks, Portuguese, seen as mestizos of Iberians and Latinos, and, at the top, the Aryans, that is to say, Germans, Slavs and Saxons [2]. As a result of the historical stage of the formation of Brazilian society, the main matrices should be analyzed in their most relevant aspects, in order to highlight the elements of hatred that were constituted and under what aspects these are sustained.

\section{Indians and the Lusitanian Interest}

The Indians were for the Portuguese individuals who were to be used in the civilizer process as workers and settlers of the newly conquered territory. The process of submission of the Indians began with the Jesuits, who did not serve the interests of the Portuguese administration, seeking to defend the interests of the Church with the spread of the Catholic religion, leading to summary and brutal enslavement and, at least, making them subjects of the crown. The proposal of the Portuguese crown, in principle, was not to eliminate the Indians, but to make them useful, according to their interests. Pombaline laws were created in the sense of preventing both enslavement and segregation. Notwithstanding such an attempt to include the Indian, the resistance to European customs and customs, arising from the colonial submission advocated, the occurrence of conflicts still lasts until the 21st century. At first contact, the showy and effective tools made the settler an ally but, over time, became an enemy because the European style of life imposed was totally different from that of the Indian.

The way of life based essentially on agriculture, hunting, and fishing, in which only enough income was available to live, without a political or statist organization, led the Indian to an inhospitable reception of the colony's lifestyle, profit. The Indian, accustomed to spending days in reserve, with full freedom, working only when necessary, would be forced to work all day, without rest, in exchange for tools, clothing and divine purification. It is added to this element the imposition of cultural adaptation, to the uses and customs of the colony with total oblivion of the indigenous culture. These conditions led to the Indian's unhappiness with the colony, due to the occurrence of conflicts that almost led to Indian extermination, with the exception of those who fled and still flee, kills within, the civilizing process.

In fact, the Indians who took refuge in the hinterlands, forests and forests are a minority among the many others who were dominated and those who preferred to integrate themselves into the colonial lifestyle and even, often, participating in wars against their own genetic matrix. Evidence that indigenous culture has been maintained by the Indians themselves who have integrated themselves into Brazilian society, adapting to the social dictates of the Portuguese Crown persist in the centuries, possessing remarkable characteristics of their culture intertwined with the existing social system. Indians and Brazilians oppose themselves as ethnic alternates in an irreducible conflict, which never gives way to a merger. Wherever a tribal group has an opportunity to preserve the continuity of its own tradition through the coexistence of parents and children, ethnic identification is preserved, whatever degree of assimilative pressure it may experience. Through this acculturation, however, the Indians become less and less Indian on the cultural plane, ending up being almost identical to the Brazilians of their region in the language they speak, in ways of working, of having fun and even in the traditions they worship. Nevertheless, they remain identified with their tribal ethnicity and are thus identified by representatives of the national society with whom they maintain contact. The step taken in this process is therefore not, as was supposed, the transition from the condition of Indian to that of Brazilian, but from the situation of specific Indians, invested with their attributes and living according to their customs, to the condition of generic Indians, each but increasingly Indians in their ethnic identification [1].

It turns out that the great colonial force of imposing a culture different from the indigenous one succeeded in inserting them, but it was not able to dethrone the indigenous culture of the cultural root of the Brazilian society. However, the ingrained and dogmatic notion that the indigenous population is of a lower culture pervades for generations in Brazilian society, and it is not clear to many that the indigenous ethnic matrix of Brazilian society is the only one that really originated and developed in Brazil since before its discovery by the Lusitanians.

\section{The black as the Driving Force of Development}

No less important, African blacks have their influence in the formation of Brazilian society, given its essential role in building the country's wealth, being the driving force of the economy, in the early days of the construction of the colony. The origin of the black ethnic Brazilian matrix comes from the African continent, not having only a single culture, language or religion. The African cultural diversity inserted in Brazil was precisely due to the arrival of slaves from various countries, each of which had specific customs and customs. Neither the exact places of origin nor the number of slaves brought to Brazil are known. They were shipped in ports along a large stretch of the west 
coast (Guiné to Angola) and a smaller segment of the eastern coast (Mozambique) and probably would have been captured in nearby inland areas. They came from different "nations," they spoke different languages, had heterogeneous religions and cultural development, and even superficially they seemed to belong to several "races." They were cataloged according to general denominations ("black", "slave", "pieces of Africa", "living fôlegos", etc.) or more particular ("black mine", when they came from the Coast of the Mine; when they had been shipped between Guinea and Angola, thus differing from the "Contracoast", etc.), however different their languages, tribes, customs, religions, etc. Considered as things, they were sold and branded, with no consideration of any other order, other than the strictly economic. Brazilian blacks therefore come from different "races" and, like whites, derive from an extensive area characterized by great cultural and biological differentiation [3].

African culture was restricted for a long time only to blacks who, prisoners, kept keeping alive their customs with the restricted practice of dances, rituals and conduct proper to the closed environments in which they were housed. It must be emphasized that there was a policy among their masters of avoiding keeping slaves from the same ethnic group together, to curb flight and riots, which further hindered the maintenance and propagation of African culture. Thus, the Negroes underwent a process similar to that of the Indians, to incorporate the lusitana culture to the detriment of the own one, but not leaving the roots to the forgetfulness. The Negroes 'better acceptance and absorption of Lusitanian culture, coupled with the Indians' reduced labor capacity, as a result of their way of life, provided the Negro with a social rise from the level of motor force to colonizing force, having functions to pass to others recently arrived slaves work techniques and colonial customs and customs, always using the Portuguese language as the main form of communication. This fact caused changes in the pronunciation of that language, which led to the appearance of accents. However, black culture, still constricted, emerged from a subaltern society parallel to colonial society.

In the large sugar plantations, it was easier for blacks to maintain a hybrid African culture because black slaves constituted the vast majority. The number and variety of Afro-influenced plantations in places such as Rio de Janeiro, Pernambuco, and Bahia were the reason why Afro-Brazilian culture became so dominant. In the hinterland, the slaves were in close proximity to indigenous and Portuguese cultures. In many ways they worked side by side with these groups, which blacks could not have done elsewhere because there were no large groups of whites or Indians nearby [4]. The pretension of the colony has always been the prevalence of dominance of the Lusitanian culture over the others, it was not for nothing that Jesuits participated in this process as diffusers of Catholicism and the Portuguese language. The role of the Hereditary Captaincies of populating and dominating the indigenous population cannot be overlooked. It happens that the later moment to the Captaincies asserted the implantation of a model of society, being the blacks and the Indians elements that should be absorbed, not discarded.

The cultural miscegenation at the beginning of the colonization of Brazil had, therefore, the culture lusitana like dominant, but that with the time gained the insertion of own elements of the black culture and indigenous. The great engine of the Brazilian economy, the Negro, played multiple roles in the Portuguese colonial system. The manual laborer who ran farms from different regions of the country was more mature and was developing the role of foreman, leaving more of the senzala and beginning to frequent the Casa Grande, absorbing new habits. Slave women, who would serve their masters and their ladies in domestic affairs, would be sexually courted by whites, who would either love them or prostitute them to other whites. The access to other functions by the blacks caused the opening of the culture lusitana to the black culture, but never enough to change the preponderance of the Portuguese culture on the others. But the influences of black culture reverberated in Brazilian society, many elements were introduced by slaves who had the function of caring for white children and they passed stories and stories of African culture. Thus, the customs and customs of the Negroes were, little by little, intertwined with the Lusitanian and indigenous culture.

But the bulk of the beliefs and practices of sexual magic that developed in Brazil were colored by the intense mysticism of the Negro; some brought by him from Africa, others African only in technique, using indigenous bugs and herbs [5]. It should always be emphasized that the colonial period did not admit the black as part of society, but only an engine of economic activity, labor force. A machine that could be bought from Africa to produce coffee, sugar, among others. The Indian, likewise, had the same function, but, over time, his weakness and reduced labor capacity were perceived. The insertion of the Negro and the Indian as a member of society would only take place a long time later, which in modern society still requires the legal construction of elements that ensure them protection against discrimination and racism. The circumstances in which blacks were introduced into Brazilian territory are the roots of ultrageneralized judgments bases of prejudice. Exposing the black as a minority is not in keeping with historical facts and reality. The driving force of Brazil's economy was the Negro who was brought into the thousands of Africa as a commodity, an object of value that had no culture of any kind, only brute force. This circumstance was presented to many farmers as an immovable fact, and it is not believable that the Negro could have any type of culture, since the European culture, especially the Lusitanian culture, was the same as the one prevailing in the others, especially in the situation of colonizers. cultural domain was a consequence, since there was no need to extirpate the cultural roots of blacks. It turns out that by the thousands, the Negroes continued to devote their culture, even in a reserved and secret way, away from the eyes of the Jesuits and whites. 
The black population grew greatly in the sixteenth and eighteenth centuries, not only because of its reproduction but also because of the increasing influx of slaves to replace the old and the sick, or those who died because of illness and overwork. The exact quantity is unknown due to the absence of numerical data of the time. However, based on the population needed to maintain the population volume, based on its vegetative growth and navigation charts, a number can be predicted. As a result of his calculations, considering a decreasing annual rate of replacement, ranging from $5 \%$ in the sixteenth century to $2 \%$ in the nineteenth century, admits a global membership of 75,000 blacks for the sixteenth century, 452,000 for the 17 th, 3,621 000 for the eighteenth century and 2204000 for the nineteenth century, adding up to a total of 6,352,000 slaves imported from 1540 to 1860 . These numbers of hypothetical demography do not count on the quantity generally admitted in the primary sources [1].

Another element to be considered was the high number of female slaves. The pretension of the entry of blacks in Brazil was intended to develop the driving force of the economy, especially labor. The reason for this number came from the lewdness of the whites before the black women who possessed them as lovers. Similarly, but with less intensity, the Indies were enticed, often having relations with blacks, providing a mixture of cultures and ethnicities among blacks, Indians, and whites. The historical peculiarities of the ethnic matrices of Brazilian society clearly demonstrate that the model to be implanted focused on the culture of the white that came from Portugal as a colonizer, the Negro being the merchandise from Africa to work as a slave, developing the economy basically, and the Indian considered as wild native of the territory that should be dominated and, if not, exterminated. With the political evolution of the Brazilian State and the adoption of abolitionist measures, the role of the black as a driving force was altered, but the perception that it would only function in the manual labor persists as an appraisal judgment in groups that cling to such evidence of ethnic matrices to support hateful thinking.

The end of slavery would not be the end point for the effective insertion of the Negro in Brazilian society as a member. The transition from slave to citizen necessitated a series of elements, among them, their survival. After leaving the land of the Lord, having his freedom assured, an element he always wanted, he did not know how to provide for his sustenance since he only had the strength and nothing else, not having tools and even land to cultivate. After the first abolitionist law - the Law of the Free Belly, which frees the son of the black slave woman -, in the areas of greater concentration of the slave, the farmers had to abandon, on the roads and in the nearby villages, the black ones' they were no longer obliged to feed. In the years following the Free Belly Law (1871), dozens of shelters were set up in the towns and cities of the state of São Paulo to accommodate these children, thrown out by the farmers. After the abolition, after leaving the working blacks who no longer wanted to serve the old masters, followed the expulsion of the old and sick blacks from the farms. Numerous groups of blacks then concentrated at the entrance of towns and cities, under the most precarious conditions. To escape this starved freedom, they began to allow themselves to be drawn to work under the conditions dictated by the latifundio.

The situation experienced by the black man of freedom was only illusory, since he would go on to work conditions identical to slave labor, but in the meantime a meager pecuniary reward for his services. Capital that would be spent on their basic necessities, since the landlord would not have obligations of food or housing, that is, the freedom of the slaves brought only the possibility of choosing to live in peeps of society or submissive to the harsh conditions of work. Stigma that endures as a general judgment. The colonist, then a landowner, expanded his offspring in the city, while the Negro expanded, in smaller numbers because of the high level of mortality, in the outlying areas of the city, not by choice, but by the condition that was imposed upon him. There was no other possibility, since returning to his homeland, Africa, would require resources that did not possess or return to the status of slave to seek entry in slave ships that eventually returned to the country of origin, which was improbable.

\section{The Racial Miscegenation and White Overlap}

The scientific evolution of the eighteenth century provided advance in the manufacturing processes, with the creation of machines that would render the slaves obsolete in some stages of industrial production. Thus, blacks and Indians were increasingly persecuted, having to take refuge in quilombos or in distant Indian villages, preferring some who believed in prosperity, to live in the neighborhoods of towns, farms and industries. Without providing what the Portuguese sought: labor specialized in the conduct of industrial machines; the manual labor was the only form of work correlate. At that moment in history, the development of scientific studies on races, which favored and favored the promotion of racism for many centuries, was linked to the social, political and economic isolation experienced by blacks and Indians, which only contributed to fix stereotypes. These technological innovations, added to the aforementioned more advanced forms of social ordering to these ideological instruments of control and expression, provided the basis upon which Brazilian society and culture was built as a European colonial establishment. One and the other, less determined by their singularities resulting from the incorporation of multiple traits of indigenous or African origin, than by the Portuguese colonial regency that conformed them as a Lusitanian branch of European civilization.

The promotion of the idea of the existence of races crossed the notion of the need for a process of laundering the Brazilian population within a period of three or four centuries. This perspective was stigmatized to the point of exposing the unfeasibility of the nation by a complete miscegenation. The idea of eugenics, or racial hygiene, current in the world of the 
nineteenth century, expanded as a true scientific notion, in which humans would be divided into races. Using an understanding of evolutionary thinking in which the evolution of living beings would be correlated with the evolution of humans, thus establishing the notion that there would be lower and higher races. Soon the Indians, who in the Brazilian territory were in the arrival of the Lusitanians, came to be considered as savages in the same way to the black man who had long been enslaved by the Old World, would be inferior races, besides the yellow and mixed, to the looks of the European studies that showed the necessity of the purification of the race for the better development of the nation. Count Gobineau (1816-82), author of Essai sur l 'unegalité des races humaines (1853), was also in favor of an absolute racial determinism and favorable to the condemnation of the individual's will, "whose will he can do nothing" (1853/1983: 1151). However, while sharing Darwinist social assumptions, he introduced the notion of "race degeneration," understood as the ultimate result of "the mixture of different human species." In fact, Gobineau cut the last lines with the monogenistic and social evolutionist explanation, inasmuch as his argument foresaw the impossibility of progress for some societies composed of "noncivilizable mestizo sub-races." [6].

The scientific perspective added racism under the ideological perspective, in which state conduct should aim at the best construction of the nation's race, with the purpose of an effective state evolution. The best race would lead to the best state. The human element, worked as science, should attain the ideal perfectibility for the attainment of a rich and powerful nation. The entry of European immigrants into Brazil, especially during the years of 1851 to 1960 , should not be left aside, having as main point of access the southern regions of the country, where they settled there and cultivated their culture in a not so influential way. In total, about five million immigrants entered Brazilian soil, fleeing from the effects of war and other crises, with the main objective of prospering and establishing residence on Brazilian soil. There was no uniformity of origin, coming from several countries, mainly from Portugal.

It is composed mainly of 1.7 million Portuguese immigrants, who join the settlers of the first centuries, made dominant by the multiplication carried out through the caldeamento with Indians and blacks. Next are the Italians, with 1.6 million; the Spaniards, with 700,000; the Germans, with more than 250 thousand; the Japanese, with about 230,000 and other smaller contingents, mainly Slavic, introduced in Brazil mainly between 1886 and 1930. Regardless of the influence that immigrants had on the cultural formation of the country, the main ethnic and cultural matrix of the country was already built, however it is undeniable that the development of such cultures on Brazilian soil provided ethnic miscegenation. Although a large part of the Indians is concentrated in the now known northern and northeastern regions of the country, the multiplicity of cultures has provided the formation of a society with diverse behavioral patterns. Brazil has several ideological matrices that formed a society with heterogeneous characteristics, possessing remarkable historical-cultural elements, which are the mainstay for the construction of ultra-generalized judgments deprived of the real role of each ethnic group in the construction of the country.

\section{Racial Democracy or Myth?}

The construction of the Brazilian state occurred with the entry of a state model directed to a society different from the one existing here, being Indians and blacks, mere extras in the Lusitanian plans, goods of use for development of the economy. The condition imposed on them was to disregard the condition of being human, precisely because of the prevailing scientific thought, whose idea of white hegemony legitimized slavery and violence for the imposition of a model of state, culture and society different from the one existing, in that Indians and Negroes had to be subjected to such abuses because they were savages and inferior races. The actions of abolitionism, especially between the end of the Second Reign and the emergence of the Republic, added to the liberal ideals coming from North America and Europe, mainly with the American Revolution and the French Revolution, led to the formation of the thought of society in estates, social classes well divided and hierarchized, still possessing great margin for racial segregation, since many only had the freedom, nothing more.

It is within the context of the crisis that put in check the slavery and social hierarchies that began to spread in Brazil, evolutionism, positivism and social-Darwinism. A significant part of the men of science adopted the perspective of racist theories to think the dilemmas and perspectives of the nation and to justify, based on the supposed racial differences, the social hierarchies that still opposed masters and slaves, but also and especially "good society" and the growing poor and free population, made up of blacks, Indians and mestizos [7].

The liberal ideals that fostered the abolition of slavery were not enough to prevent the development of racist thought within the Brazilian society that developed its identity. The diversity of institutions that deepened their doctrines in spite of the racial theme provoked a greater social split, being the base science unquestionable of such understanding. The discovery of new territories and new peoples inspired the men of science, who ascribed imperiously to the sovereignty of the white man to the detriment of the newly discovered peoples. The savages, understood as primitive beings, deserved detailed studies on what impacts to a society in formation they would entail and on how and in how long the process of miscegenation, with predominance of the white race occurring. This process, for them, would be natural and culminate in the laundering of the population.

\section{Eugenia}

The development of studies on the races followed the historical evolution of the man who developed from all perspectives. The man was taking strides to seek mastery in the 
sciences. The study of biological species had the same effect. One of the major works on evolution, which unleashed a huge range of other studies in the field, was Charles Darwin's "The Origin of Species" (2003), published in 1859. The work itself did not address the subject, but the cited author "[...] in 1871, the work Descent of man, and selection in relation to sex, sought to extend also to human beings the same principles of natural selection [8]."

Darwin [9] analyzed elements that for the time faced principles and dogmas. Naturalists and the Catholic Church conducted the treatment in a uniform way despite the theme, with the immutability of species as a flag, where each living being would be created separately and had no connection whatsoever. With the evolutionary perspective, introduced in 1859 , the studies turned to its applicability on man, since the author did not go into the subject. Francis Galton [10], who coined the term eugenics, is a Greek word for "well born" as a branch of science dedicated to the study of human races. From that moment on, Eugenia proceeded to indicate Galtonian pretensions of developing a genuine science of human heredity that could, through mathematical and biological instrumentation, identify the best members-as with horses, pigs, dogs, or any animal- bearers of the best characteristics, and stimulate their reproduction, as well as to find those that represented degenerative characteristics and, in the same way, to avoid reproducing them.

Natural selection introduced by evolutionary theory was gaining new contours, now under the aegis of the transmission of characteristics, in which heredity should be systematized. The development of the studies carried out by Galton [10] was aimed at systematizing the transmission of characteristics. However, in comparison to the studies of Darwin \& Galton $[9,10]$, the first author focused on the elements that could interfere in the formation of the species to reach the best physical shape. It occurs that these species were irrational. Already Galton [10] sought, in addition to the best physical form, the best mental form of man, demanding greater systematicity, predictability and predicted by him and introduced in his research, mainly by means of questionnaires. However, both studies concluded: the natural selection of species comes from the transmission of the characteristics. Thus, reproductive methods had a greater impact on population improvement than improved social conditions.

What is true for the entire race is equally true for its varieties. If we were to select persons who were born with a type of character that we desired to intensify, - suppose it was one that approached to some ideal standard of perfection - and if we compelled marriage within the limits of the society are selected, generation after generation; there would be no doubt that the offspring would ultimately be born with the qualities we sought, as surely as we had been breeding for physical features and not for intellect or disposition. Collaborative thinking represents a perspective that for a long time has taken root in science as a valid theory, prevailing in the culture of society and fostering social cleavage and racist theories. In the old World, these studies were increasingly being considered in policymaking, using practices of social separation or miscegenation or, often, extermination, with the aim of removing lower races from the population that could interfere with growth. Measures such as prenuptial examinations, restriction of procreation in the elderly, degenerative diseases, or people with alcoholism, as well as other mental disorders, were indicated to governments for greater biological control in order to allow the population a level of perfection that would provide the country's growth.

The conduction of such proposals to governments was considered when analyzing immigration policies, health, education and others, since, scientifically, there would be no progress in the population with social policies. The analysis pointed out by eugenics provided an inefficacy of such elements as methods of advancement in the improvement of the population. Thus, reproductive measures, indicated by eugenics, would be the best way to reach a perfect population. The studies of the human races, coming from Europe, had by epistemological genesis the same study of the animals, as already asserted. The use of such methods stems from the fact that heredity was pointed as the main factor of transmission of characteristics, good and bad, physical and intellectual. One example is the creation of the best racehorse. The best lineage must prevail for success in horse racing.

Last but not least, we may identify a third field in which the concept of "race" was omnipresent before the eighteenth century. It is this field which we should look to in order to study some of the main elements that constituted the concept of "race" in natural history. This field, however, was also deeply connected to nobiliary practices. I am referring to breeding practices, and especially to horse breeding. Breeders considered race to be a specific object of knowledge and power. Through a variety of practices, they attempted to control the reproduction of the animals they had chosen in order to produce the best descendants, thus obtaining a good race. Issues such as the reproduction and conservation of a race's qualities were thus fundamental to breeders, and in this field, "race" was mainly reduced to mere natural characteristics (which was not the case in questions of nobility). A race's improvement and preservation consequently implied taking care of the entire range of animals' natural functions: reproduction, nutrition, and living conditions [11].

Government policy, then, shifted to the cleavage between members of the population considered perfect and newly discovered savages, including in this group those who would have social conditions that would prevent them from being equated with the perfect. Segregation, if not possible, led to the adoption of more extreme measures such as extermination, abandonment, among others. Eugenics, as a science dedicated to the pursuit of the best human race, was divided into a positive 
one, for the necessity of pursuing perfect lineages with the use of reproductive methods; and negative eugenics, due to the form of treatment of humans considered imperfect, and it is necessary to practice segregator measures that should, in theory, protect the perfect race from the negative characteristics borne by imperfect individuals.

The scientific analysis of the concept of human race at the end of the eighteenth century had a polarization when the hypothesis of degeneration of the races emerged, "[...] they were called degenerate species considered inferior, because less complex in their organic conformation." which with the turn of the century came to be known as pathological deviation. The studies advanced to deterministic perspectives in which criminal anthropology was embodied in the physical analysis of criminals, exposing biological traits as objective evidence of murderers and other types of criminals. Man's relentless pursuit of the best physical and mental completeness of himself and his offspring culminated in the attempt to systematize eugenics based on scientific arguments and the hope of improving and perfecting the human species through the reproductive control of individuals [12]. Thought about human races has spread and prevailed for a long time throughout the world. The consequences of eugenics were felt throughout the nineteenth century, in which racist theories, social segregation, deep-rooted feelings of prejudice, discrimination and racism developed within society, which fully absorbed scientific analysis, still in the course of the nineteenth century, religious and social elements in biological characteristics.

\section{Democratic Republic of Brazil}

It occurs that, while science, especially the eugenic, inquired the reasons why there were human beings with multiple characteristics, social evolution caused the estates to be marked and to create a great insurmountable gap between different types of classes. In the United States, social cleavage was marked by a crystalline division between southern and northern states, some liberals and other conservatives, a fact that still generates many cries of all kinds today. In the same split, Europe showed its peculiar aversions to the Jews, not excusing itself from the ingrained feeling of superiority before the newly conquered savages and in study. However, the feeling of travelers and scholars passing through Brazil was that there was no social division here. The message received by the world, and even welcomed by the Brazilian people, was that the Negro or the Indian, before the abolitionist policies could ascend socially.

The social miscegenation, existing at the time in Brazilian society, reflected the lack of racial discrimination. It is evident that during the nineteenth century the culture of social cleavage by reason of the color of hair, sedimented by scientific notions of different races, one superior to another, preconized the society in classes. Each class has its composition and was very different from each other, and, as in other countries, social ascension is impossible. The Negro, for example, during the colonial period was restricted to its place of slavery, leaving its culture delimited to that space. With the abolition of slavery, his position of slave became that of salaried but with little bargaining power. This perspective did not correspond to European and American thinking, leading to the belief that in Brazil there was a racial society.

However, the Negro, in particular, did not cease to suffer from the stigma of slavery with the validity of the Republic in Brazil. Criminal laws were directed, not by chance, to acts that represented the existence of the Negro in society. The Criminal Code of the Empire, of March of 1830, established severe penalties to the blacks by virtue of practice of acts, like the capoeira. Likewise, the Penal Code of 1890 only abolished the death penalty, but established, among other things, penalties against the practice of capoeira, begging and vagrancy. With the same restriction, black political rights were initially hampered by the imposition of literacy as an element for the exercise of the right to vote and to be voted, which could even include whites, but the intention was to isolate blacks politically. In addition, the institutionalization of the slave-like thought was marked in the society and in the public distributions. The main turning point for a change in Brazilian thinking was promoted by the blacks themselves, who waged popular movements, strikes and protests against slave labor practices still used in the workplace, demanding political and social insertion in the country.

At the beginning of the twentieth century, Brazil was experiencing a great social upheaval, with popular movements of various shades: the cangaço, Padre Cícero pilgrimages, the Canudos War and the Contestado. The participation of black people was expressive in these movements, confronting the Oligarchic Republic. On November 19, 1907, Rui Barbosa published an order ordering the burning of books and documents pertaining to black slavery in Brazil. Capoeira was criminalized. Disciplinary technologies such as corporal punishment in the Navy, which had been abolished one day after the proclamation of the Republic, were legalized a year later, and were authorized by the 25-lash law for the most serious penalties [13]. The onslaughts of the population against the slave-owning practices stigmatized in society and in the Republic were not welcomed, with strong retaliations often culminating in large punishments, leading to several deaths. One prominence to be given to emphasizing the black advance in the struggle for their rights is the Chibata Revolt, which occurred in 1910, when a black sailor had been whipped with 250 rope chisels with steel needles in front of the entire crew. black sailor João Cândido, who had witnessed the punishment, leader of the Rebellion that caused panic in the city of Rio de Janeiro, by gunfire of Navy ships, dominated by the respective crews who claimed nothing more than improvements in the navy's treatment to its sailors.

In response to the demands of President Marechal Hermes da Fonseca, the Navy, unwilling to comply with them, distressed the rebels, some of whom were killed by exile, and João Cândido, 
one of the survivors, when he was hospitalized, the exposition that the existing lacerations were mere degenerations of the race itself. Collision with the science practiced at the time, eugenics, analyzed earlier. The actions of João Cândido echoed throughout the country, encouraging the development of groups aimed at ensuring in practice the emancipation of the Negro as a member of Brazilian society. Other popular movements emerged with the same fury always advocating the black's political and social insertion. In this context, the black press came to equate the integrationist discourse of the claims, providing a massive voice that echoed with force, that would allow the black political organization of the black with the foundation of the Black Front Brazilian.

At the same time, the Brazilian population, especially the region of the state of São Paulo, received immigrants of all ethnic origins, but all of them from Europe, who brought to Brazil thoughts different from the racial moment that emerged. European immigrants brought with them eugenic thinking, and because they were better trained, they assumed important positions within the working and bourgeois estates, creating separatist air, since blacks, and the whites themselves, settled and born here, felt excluded from their own environment. The development of the debates on the racial question in Brazil, however, was only among blacks, given their political organization and the press itself, to propose to the debate internal issues of the black community. Some members of this community ascended economically and intellectually, leaving the black diaspora group, creating a social hierarchy of their own. With the happening of events, like the Congress of the Brazilian Mocidade, the profile of disintegrator was dressed against the own movement, creating a racism on the part of the own black.

These movements served to reinforce feelings of loyalty to the existing social order between "whites" and "blacks" and to make them aware of the desirability of formally regulating the guarantees of legal and political equality before the law, leading to the inclusion of a combat the prejudice of color in the Constitution of 1934 [13]. With the awakening of this process, the integration of the Negro into the country began. Its insertion would be absolute, covering all aspects of life in society, religion, work, economy, politics, all sectors of the country, in particular, the institutions themselves would have the integrationist policy as the north to be applied in their acts. With the government of Getúlio Vargas, the Estado Novo, the implementation of popular policies that ensure this insertion advanced, mainly through the legal route with the advent of the labor legislation that mainly benefited the working class in its large part formed by blacks, Indians and mulattoes

The proposal for absolute racial insertion would not succeed if the thinking of the dominant society did not reverse. Many sectors were still reluctant to accept blacks as members of Brazilian society, national identity was not yet built. Attitudes of cordiality towards blacks would be assumed but stigmatized. The participation of the intellectuals of the time for the development of a national identity that provided the creation of a social environment of inclusion was massified, with Gilberto Freyre as the "Casa-grande \& Senzala". The intellectual, legal and racial integration policies favored an environment of racial insertion. Contrasting with institutional actions, society did not willingly and fully and totally absorb this perspective, still acting with racist practices towards blacks, Indians and mulattoes. It would not be a peaceful process of induction, despite the fact that blacks' litigation was, since the abolitionist policy implemented still had repercussions within society, but the actions constituted aimed at breaching a racial democracy.

My understanding ... is that we must see in the "racial democracy", also, a political and social commitment of the modern Brazilian republican state, which has been in force, alternating strength and conviction, from the Estado Novo de Vargas until the military dictatorship. Such commitment consisted in the incorporation of the Brazilian black population into labor markets, in the expansion of formal education, and finally in the creation of the infra-structural conditions of a class society that undid the stigma created by slavery. The image of the Negro as a people and the banishment in Brazilian social thought of the concept of "race", replaced by those of "culture" and "social class", are its expressions [14]. It was not to be underestimated the efforts made by all institutional areas for the purpose of building racial democracy in Brazil, which generated favorable results for the development of the national identity of the Brazilian population. The sentiment devised by many echoed in other lands to the point that many believe that "Brazil is known throughout the world for its racial democracy. Racial prejudice and discrimination are relatively moderate [...] ".

On the other hand, the entrenched stigmata of the recently closed era of the slave-owning age in the wealthier classes were held to be unbelieving in racial democracy, not forgetting efforts to remove any kind of social ascension from the other lower classes. The real conjuncture was aimed at clashing with these still persistent racist manifestations, institutional efforts were evolving after the Estado Novo, and even in the military dictatorship, all aimed at showing, in an evident way, that the Negro, the Indian and the mulatto were part of society, the history of the country and constituted the national identity of the Brazilian people. Affirmative action still echoes in the 21st century, both in its consequences and in new forms of social inclusion policies, and there are still stigmatized feelings that have taken over a slave ideology. The necessary historical revision, however, points to the evidence that racial democracy does not represent a status that remained present during a particular political epoch of the country, but rather a necessary condition for peaceful coexistence and the formation of the country's national identity.

As a social imaginary, the Myth of Racial Democracy is a horizon: it is not an object among other objects, but an absolute 
limit that structures a field of intelligibility and that is, therefore, the condition of possibility of the emergence of every object. Therefore, the Myth of Racial Democracy is not merely a belief, or false consciousness, but a mode of functioning of discursive practices, a mechanism [15]. The development of public policies aimed at inserting the Negro, the Indian and the mulatto into society as recognized members of national identity in the $21 \mathrm{st}$ century represent nothing more than the search for the full implementation of racial democracy, which since the abolition of slavery has been gaining strength and strengthening in political and social structures, advancing the overthrow of prejudice and the deconstruction of generalized judgments that generate stigmas that leverage the practice of racism. literature, but the actions and behaviors that consummated this term have long been practiced. The greatest consequence of this thought was the paradigm shift in the treatment of blacks, Indians and mulattos, who would no longer be seen by their color, the hitherto considered race spread by eugenics, but by the class. In a miscegenated way, the Brazilian people were led to abandon this eugenic circumstance to adopt notions of people of multiple ethnicities, consubstantiated in social classes.

This did not prevent the existence of racistand discriminatory conduct by the hegemonic class that did not accept the new class socially. The contrast between racial democracy, represented by political practices and discourses, and the racist attitudes of society, brought a total incongruity between society and government. While many intellectuals practice the discourse of racial democracy, others deflorate pointing to myth. In other words, the denunciation of the "myth of racial democracy", which supported all black mobilization and protest in the following decades, summarizing the distance between discourse and the practice of prejudice, discrimination and of inequalities between whites and blacks in Brazil, is finally exhausted as an academic discourse, even though as a political discourse it survives with some efficiency.

The real expression of racial democracy then survives as a mere political element, for in fact what existed, and still exists, is a valid political proposal of insertion and social miscegenation, but which in practice did not affect other classes that persisted, and persist in biased and racist acts. Political actions culminate in the twenty-first century, as well as the sense of hatred that surrounds the wealthier classes, contaminated by eugenic thinking that dominated most of the eighteenth and nineteenth centuries.

\section{Neonazism: from the Jew to the Northeastern}

The Brazilian society, made up of whites, blacks and Indians, had as white the Lusitanians and immigrants, coming from the most diverse regions of Europe. Racial miscegenation was imminent, as was the spread of the cultures of the peoples of Brazil. Among the most diverse cultural elements transported, the fascist ideology contaminated the political scene, and was transmuted, for many in actions that adhered to the Nazi policy of anti-Semitism. Since it is unnecessary to look at all the differences between fascism and Nazism, an element of prominence to be evidenced in this separation is anti-Semitism. There was not a Nazi government in Brazil, but a fascist government that developed an anti-Semitic immigration policy, not showing a Nazi government, in addition to other factors that pervade the peculiarities of each regime.

\section{Anti-Semitism in the Vargas Era}

Preceding the emergence of the Estado Novo, the preoccupation with the Brazilian national identity led to the study of the population at the beginning of the 20th century, in particular, analyzing eugenic and anti-Semitic ideals that awoke in the authoritarian environment that was being formed. The population of Jews in 1920 in Brazil consisted of 15,000 people and grew to 75,000 in the 1940 s, the result of an immigration wave stemming from the anti-Semitic persecutions perpetrated by authoritarian regimes in Europe. From this population evidence, the actions to contain Jewish immigration were visible. The outcome of these actions occurred precisely because of the political environment in Brazil.

Thus, with the rise and participation of a commercial and industrial bourgeoisie in the spheres of power, with the emergence of extreme right-wing political groups and the formulation of a Church-State pact, snaking through the exalted liberal values, the recovery of racial ideas [16]. The trajectory of the Brazilian fascist political course is due to the international proximity existing at the time between Brazil and Italy. The Italians developed a policy focused on the problem of the demographic surplus that occurred in the 1920s in Italy, precisely seeking international agreements on emigration with the country that was in the process of agricultural industrialization. But not only would emigration be the goal of Italian politics, which sought to give all cultural and ideological support to Italians living abroad, so that they could spread Italian thought throughout the world. In the 1930s, the separatist movements of the southern states of Brazil grew, and Italy was inclined to support these movements, since most of the Italian population was concentrated in that part of the country and collided with the Italian proposal of empire expansionism.

The Integralist Action of Brazil, a movement with the status of a political party, which emerged in 1932, was aligned with the fascist doctrine, receiving Italian support in what was called Latin fascism. Thus, fascism ran through the political sphere that preceded the Estado Novo, the feeling of political reconstruction emerged with nationalism as a strong base of support for the new government that would emerge. On the opposite side Communism and Judaism opposed the Integralists in an attempt to implant political ideals in the state institutional emergency that plagued the 1930s. At the same time, the press disseminated the events of the Spanish Civil War by presenting communists as terrorists to society Brazilian, relating them to Bolshevism and the Jews. The National Liberation Action suffered repression and 
lost space as a leftist movement, in addition to stifling the stigma of Communist and Jew being opposed to the homeland and social peace. Authoritarianism emerged in the alcove of nationalism, culminated in the coup of 1937, leading to the rise of Getúlio Vargas, who sought to make the state strong and centralized in the person of the supreme chief, adopting in many actions the fascist doctrine, being welcomed by Italy and receiving your support.

The prevailing eugenic studies in Europe still echoed on Brazilian soil and many government intellectuals applied them in public policies, especially regarding immigration control before the Second World War. In addition, nationalist sentiment was rooted in society that felt threatened by the insertion of immigrants in the urban centers that ascended commercially, overthrowing Brazilians from their posts. The fear that more immigrants would enter urban centers and prevent the commercial advance of Brazilians allied with immigration policy, eugenic thinking and the then realistic, inclusion of the Jewish religion as an inherent element of the race. On the other hand, the strengthening of anti-Semitic policy spread throughout Europe, spreading in a spreading of persecutions that impelled the Jews to embassies and consulates of other countries in search of a refuge, of a home, being Brazil an excellent place to have home, for its agricultural, industrial and commercial evolution.

Brazil, however, closed the doors to them by adopting restrictive measures in the name of "building a strong nation, a eugenic race and protecting the unemployed." Officially he enumerated the "enemies of the Homeland" endangered by the presence of elements considered undesirable, harmful to the constitution of a national identity. Together with the representatives of the yellow and black race, Jews (generically termed "Semites" and treated as race) became part of the list of elements considered to be racially, ethnically, politically, socially and morally harmful [17]. The treatment accorded to the Jews, entitled by the Estado Novo as Semites, restrains their immigration by means of objective criteria for the granting of visas, being restricted to tourists, depending on the origin and with a limited amount. The stereotype of the Communist Jew, the inferior race, who came to the country to withdraw his job from the Brazilian was deeply rooted in the political sphere and also in society, causing an element of hatred that reverberates in the 21st century with neo-Nazi movements that spread anti-Semitism and persecute Jews. Despite the actions of the Estado Novo aimed at preventing the immigration of the Jew, many managed to circumvent the Brazilian immigration rules, obtaining a refuge in the country. In any case, anti-Semitic sentiment was present and strengthened in the Vargas era, both politically and within society.

The Brazilian elites believed that the insertion of the Jew in Brazil would occur with the purpose of occupying the commercial gap existing in the agricultural economy, so much that the project of immigration was directed to the agricultural production regions of the south of the country, but its insertion took place, also, in the great urban centers, where they ascended economically in other sectors. In addition, the customs and customs of the Jews, especially regarding aspects related to their religion, remained practiced without any kind of concern with the peculiar Brazilian identity with Catholicism, which raised the degree of rejection of the Jews before the Brazilian elite.

\section{Nazi influences and Neo-Nazism}

Still on Integralism, in the period before the Estado Novo, there are those who sketch the influence of the Nazi ideology regarding Jewish hatred, both because the majority of German immigrants were settled in the south of the country, the cradle of the Integralist movement, as well as by the nationalist sentiment, sustained by the Nazis who aligned themselves with the political moment of search for the national identity that passed the country. In the 1920s, the Nazi Party had about 500 affiliates out of 25,000 German immigrants based in Santa Catarina and Rio Grande do Sul. The dissemination practices of Nazi ideology occurred in schools and newspapers but were not restricted to the south of the country, since the visibility of the German authoritarian regime spread throughout the world with the economic crisis of 1929. The crisis of liberal democracy, the good results achieved by totalitarian regimes and its opposition to Communism contributed to the popularity of fascism between Luso-Brazilians. It can be said that much of the press in the state of Santa Catarina was sympathetic to fascism, at least until 1938, because relations between Brazil and Germany were quite profitable. An example of this was the trade relations between the two countries which, with Hitler's rise, developed considerably, so much so that in 1936 Germany overtook the United States in imports into Brazil, and exports from Santa Catarina had the Germans as his second best buyer, only losing to Argentina [18].

The Nazi dress in the fascist ideals practiced in Brazil declined with World War II but was not decimated. Nationalist sentiment has been preserved in far-right movements that are spreading throughout the world. Mostly young, rebels who aligned themselves with anarchy and were adept at violence. These movements emerged in the 1960s with reflective effervescence of cultural and moral values, occasioning major episodes of history such as the Negro struggle in the United States, Tropicalism and hippies, emerging with the "shaved heads", or English-language skinheads. In the latter case, there was no nationalist political perspective, but rather a feeling of belonging too much to a country to the point of erupting into violence against foreign groups or having any kind of characteristic different from its own. In sequence, the punk movement emerged in order to differentiate itself from the others, mainly from political institutions, and the most distorted objects and attitudes of reality were used to represent this movement, appropriating Gothic elements, including the Nazi style, as boots, wearing pants with suspenders and swastikas. The influence of these movements soon arrived in Brazil, with 
groups called Caracas do Suburbia and White Power. The political connotations are details that did not interest them, although some groups practiced an exclusionary ideology introduced by Nazi thought widely used as far as the perspective of race was concerned, but the peculiarities regarding the organization and practice of violence without modesty were written and repercussions as characteristic elements of these groups.

There are about 12 neo-Nazi groups in Brazil, mainly in São Paulo (capital and interior), Rio de Janeiro, Espírito Santo, Paraná, Santa Catarina, Rio Grande do Sul and Brasília, and indications that they are beginning to organize themselves in some capitals of the Northeast. Its origins are twofold: (1) those who call themselves the rightful heirs of the late Integralists of the 1930s, followers of Plinio Salgado, who drink directly from the sources of Benito Mussolini and Adolf Hitler - include liberal professionals such as lawyers and journalists, retirees, tradesmen, housewives, university students, may be young or older, generally conservative, ascetic; 2) the new "bald" skinheads, whose early groups appeared in the late 1970s - mostly youths of proletarian or lower-middle-class origins, gang-aggressive, wearing fur, short hair, or shaved, wore jeans, caps, hoods and with tattoos (dragons, flags and dogs) scattered around the body. They carry chains, punches, and revolvers as weapons; usually practice weightlifting, bodybuilding and martial fights (kung fu, karate, chutebox, etc.), in permanent worship of physical form; are against the consumption of alcoholic beverages and drugs [19].

Neo-Nazi movements did not have a political stamp, but an anarchist extremism that preached the defense of the group considered as unique element of national identity, not admitting any type of disparate element. The combination of the rebel movements from the 1960s to the 1990s developed in an environment where the world was experiencing the Cold War and cultural and social revolutions, where values were mutated at all times and aligned to a line for the young the feeling of belonging to the process often meant having a national identity. The proliferation of the neo-Nazi movements gained political ground with the formation of radical parties, both right and left, in which groups of violence were aligned. In Europe, the anti-immigrant discourse still echoes the fears of recession in the economy, providing the formation of groups aimed at discrimination against immigrants, aligned with the parties of National Fronts, such as Faisceux Natiotialistes Européens (FNE), Parti Nationaliste Français and Phalange Française in addition to the international branch group National Front.

The movement also echoes in the United States where, faced with the legal treatment of freedom of expression and the bipartisan political system, neo-Nazi groups are restricted to advertisements and racist manifestations. National Allience, American Nazi Party and Klu Klux Klan, are examples of American neo-Nazi groups who, through acts of violence and inflamed speeches of racism, disseminate hatred to mainly Black and Jewish groups, as in this excerpt from one of the leaders of the Klu Klux Klan in which he says: "Personally, I believe that blacks should be returned to Africa, and Jews to Israel." Noting that in this case there was no conviction, civil or criminal, to the speaker. One episode to highlight of the political participation of these groups in the United States was the candidacy to governor of Louisiana of the head of the Klu Klux Klan, David Duke, in 1991, obtaining 39\% of the votes. The observation of neo-Nazi groups spread throughout the world asserts the existence of hatred in society, harvested from the historical ills of eugenics and movements such as Nazism. By its very name, the proximity between Nazism and neo-Nazism is essentially linked to extreme nationalist sentiment and rooted in the split of groups.

However, some scholars claim that neo-Nazism differs from Nazism by failing to defend the dichotomy used by the original Nazism based on discrimination: racial superiority / inferiority. According to this theoretical line neo-Nazism is based on the cultural difference contained in the discourse of segregation of peoples. This precept supports the idea that each people must maintain their cultural and national identity in their given environment. Thus, neo-Nazism would defend incompatibility between different groups. Discrimination that was racial now would be cultural. This new discriminatory line, called "new racism", is based on the premise that "all races and cultures have the right to full and unrestricted development, but they must remain separate and independent, or more precisely, this development must take place within of the well-defined limits, within the culture proper to each one of them " [20]. The eugenic notion, based on scientific elements that sought to systematize and evidence the existence of races among humans, which has seduced racism for centuries and whose effects are still rooted in part of society adopting conservative and extremist precepts now cultural root [21-32]. For many, the definition of social class by variants of national, regional, power, wealth, culture, prestige or status evidence inequality leading to prejudice, discrimination and racism. Brazilian notions of racism still have repercussions on attitudes in which "Negroes are still described by means of supposed" Lombrosian "traits, the Northeast are still (poorly) characterized by geographic determinism - and the incidence of the sun on their brains [33-46]."

In Brazil, neo-Nazi groups target elements of color, religion, sexual orientation and national origin. Each group has its own characteristic and organization, but most of them practice acts of violence and propaganda aimed at blacks, Jews, homosexuals and the Northeasterners. Each neo-Nazi group has its own peculiarities. For example: two White Power fanzines, titled Paulista Pride and Race and Motherland, boast statements such as: "We are proud to be (sic) white, descended from Europeans and we must not give up this"; and "Long Life to the White Race" [47-53]. The first issue of the Race and Homeland, of May / June 1989, which was apprehended by the Federal Police in São Paulo, stated in his editorial: "The Northeastern / Northern 
migrant only delays our side, Outside Nordestinos, these lands are ours!!! “.

Brazilian society is composed of the most diverse ethnicities, with the most diverse types of social and ideological behaviors, the existing frictions regarding prejudice, discrimination and racism, are rooted in historical facts experienced by the country in its formation, passing through period of slavery and extermination of Indians, rise in the number of immigrants, institutional policies of anti-Semitism, neo-Nazism [54-65]. The values evidenced by the neo-Nazi groups are different from Nazism, but they take over historical elements to evidence elements of disparity that are falsified as impure and detrimental characteristics to the group. Morally and physically attacking neo-Nazis, they are repressed by the state, but they still have ideological anarchist and separatist ideas [66-75].

\section{Final Considerations}

Striking historical facts that Brazil does not have in its bowels, but not without exemption of the hatred that fed these movements. The reasons for thousands of brutal murders, racial persecutions, separatist movements, etc., stem from the unshakeable belief in a superior race that must dominate and curb miscegenation by extermination and segregation. Transforming into true dogmas, into ideologies, the conviviality with stereotypes becomes intolerable and its reasons must be scattered to reach victims and reach adherents, creating an environment of hostility [76-86].

Nazi reasons foster internal conflicts in evolved societies and provoke genocide by maintaining power. The abolition of slavery was not enough to banish from erasing the idea of white superiority. The discourse of hatred takes away human sentiment and fosters violence based on prejudices born of ethnic, religious, social, political, and other reasons built throughout history. Their purposes of discrimination are violent and reach their apex when adopted ideologically. In Brazilian society at the end of the twentieth century and the beginning of the twenty-first century, existing hate movements slyly foment discriminatory and racist behavior, culminating in acts of violence directed at minority groups. Since its discovery, Brazil had been contemplated with an ethnic multiplicity of Indians who possessed a wide cultural diversity. Most of them were dominated by the Portuguese colony that decimated some tribes, and it made connections with others, always making clear that the and that the savage was to serve him or to perish, the Indian being stigmatized by his own lifestyle as a lazy savage and unable to perform more arduous work, since he had no propensity to profit. The Indian was then seen as a problem, not as owner of himself and his lands, emerging stereotypes and being the target of prejudice, discrimination and racism.

Similarly, blacks brought in as slaves during the colonial period and a large part of the monarchy were considered disposable products used in labor by farmers and had no social participation other than the role of their master's subordinate. With the abolition of slavery, the freedom thus desired would not bring the political and social space that had been conquered, and is still for many decades, despite its role as the driving force of the country's development, the Negro was considered as an individual incapable to develop non-manual activities. Cultural miscegenation would provide for Brazilian society the division into classes, where Indians and blacks were below and whites above, and the culture of those considered a crime, as in the specific case of the practice of capoeira during the monarchical period.

In the eyes of the world, Brazil had a splendid racial democracy with the insertion of several ethnic matrixes in society and an idea of peaceful coexistence between them. It occurs that the dominant scientific current in the world, especially in the nineteenth century, exposed the existence of human races. The purpose of Eugenia was the study of human races, in search of the best lineage, scientifically going through that there would be one line of the human race superior to the others, further reinforcing the existing stigmas. Thus, acts of discrimination and racism were common, and the exercise of rights was inaccessible for many. In countries like the United States, the Negro was persecuted in some states to the point of being arrested, tortured and killed. In Brazil, due to the inexistence of racism practices such as in the United States of America, despite possible historical facts that contradict this argument, the ideal of racial democracy where peaceful coexistence was celebrated reverberated, but this was not reflected in reality. The prejudice infused within society towards the Negro and the Indian had not been mitigated, and the law itself was an instrument for the persecution of minority groups.

Black movements, through the change in the thinking of Brazilian society, have allowed the country to mature on this point, allowing the exercise of political and civil rights in an egalitarian way, yet the stigmas created were not combated, providing the emergence and development of stereotypes in the eugenic and enslaved idea, culminating in acts of hatred. Political evolution with the Republic made changes possible, but with the emergence of the Estado Novo, the search for national identity equated another element of hatred, the religious one. In particular, because of the persecution of Jews across Europe and the idea of racial democracy, many came to Brazil looking for a home, and when in Brazil they constituted not only a home, but they prospered economically.

The economic advancement of the Jews in large urban centers was seen as an invasion since they occupied commercial spaces that would be of the Brazilians. Thus, Getúlio Vargas's government, aligned with the Italian fascist ideology, started an anti-Semitic policy in the immigration corridors, in addition to the society itself to develop stigmas against the Jews due to uses and customs adopted in a way different from the local culture. It is worth remembering that many immigrants were not just Jews 


\section{Global Journal of Archaeology \& Anthropology}

but from all over the old world, and with them, their cultures and lifestyles. Many of these were anti-Semitic, worshiping Nazi Germany that had in one of its ideological lines the superiority of the Aryan race. Particularly settled in the south of the country, Nazi policy spread throughout Brazil and gained new clothing. The stigmas existing in the formation of Brazilian society, which fall on the black and the Indian, included the Jew, and opposed opposing groups considered to be harmful, creating stereotypes for homosexuals and northeasterners.

It can be seen that historical, social, sexual, religious and national values are exaggerated by individuals who are aligned with an ideology that historically supports the existence of races and their superiority. In addition, judgments of value are ultra-generalized creating stereotypes emerging situations of prejudice that are no longer restricted to neo-Nazi groups, but to the whole society that can absorb them, leading to acts of discrimination and racism or not. The elements of hatred existing in Brazilian society have developed since the formation process, with the Indian, the Negro and the Jew, and are still formed in the face of new emerging social structures, such as homosexuals and northeastern Brazilians. ideology of the superior race, now not only because of the color of the skin, but of religion, sexual orientation and national origin.

\section{References}

1. Ribeiro Darcy (1995) The Brazilian people: the evolution and the meaning of Brazil. São Paulo: Companhia das Letras, p. 38-39.

2. Moreira Vânia, Maria Losada (2008) History, ethnicity and nation: the Indian and the national formation from the perspective of Caio Prado Júnior. In: American Memory, Location, n. 16(1): 63-84.

3. Freire-Maia Newton (1975) Brazil: racial laboratory. Rio de Janeiro: Voices.

4. Miles (2011) During the colonial period, they often had to ally themselves with the indigenous community, ironically to massacre other indigenous communities. A series of these massacres occurred in the years $1666,1708,1713,1721$, and 1741 . Some of them were responsible for the death of entire tribes. pp. 33-34.

5. Freyre Gilberto (2003) Casa-grande \& senzala: formation of the Brazilian family under the patriarchal economy regime. (48 edn), Rev. Global, São Paulo, Brazil.

6. Schwarcz Lilia Moritz (1993) The spectacle of races: scientists, institutions and racial question in Brazil. São Paulo: Companhia das Letras, p. 49

7. Moreira Vânia Maria Losada (2008) History, ethnicity and nation: the Indian and the national formation from the perspective of Caio Prado Júnior. In: American Memory, Location, n. 16(1): 63-84.

8. Del Cont Valdeir (2008) Francis Galton: Eugenics and heredity. Sci Stud [online] 6(2): 201-218.

9. Darwin Charles (2003) The Origin of Species: in the midst of natural selection or the struggle for existence in nature. Translation Paul Mosque. Porto: Lello \& Irmão e-books, p. 14.

10. Galton Francis (1865) Hereditary talent and character. Macmillan's Magazine, 12: 157-166.

11. Doron Claude-Olivier (2012) Race and genealogy: Buffon and the formation of the concept of "race". Humana.mente journal of philosophical studies, 22: 75-109.
12. Mai Lilian Denise, Angerami, Emília Luigia Saporiti (2006) Negative and positive Eugenia: meanings and contradictions. Latin American Journal of Nursing. Ribeirão Preto 14(2): 251-258.

13. Sales Junior, Ronaldo Laurentino (2009) de. Race and justice: the myth of racial democracy and institutional racism in the flow of justice. Recife: Joaquim Nabuco Foundation, Massangana Publishing House, Brazil, p. 45

14. Guimarães Antonio Sérgio Alfredo (2002) Classes, races and Democracy. São Paulo, Brazil, pp. 139.

15. Sales Junior, Ronaldo Laurentino (2009) de. Race and justice: the myth of racial democracy and institutional racism in the flow of justice. Recife: Joaquim Nabuco Foundation, Massangana Publishing House, p. 36.

16. Carneiro Maria Luiza Tucci (2001) Anti-Semitism in the Vargas Era: Ghosts of a Generation (1930-1945). Perspectiva, São Paulo, Brazil, p. 47.

17. Carneiro Maria Luiza Tucci (2001) Anti-Semitism in the Vargas Era: Ghosts of a Generation (1930-1945). Perspectiva, São Paulo, Brazil, p. 70-71.

18.Zanelatto João Henrique (2011) Nazism and integralism in Santa Catarina. Annals of the XXVI National Symposium on History - ANPUH. São Paulo, Brazil, p. 6.

19. Salem Helena (1995) The tribes of evil: neo-Nazism in Brazil and in the world. Current, São Paulo, Brazil, p. 30.

20. Jesus Carlos Gustavo (2003) Nóbrega de. Neo-Nazism: new outfit for an old problem. Akropolis - Journal of human sciences of UNIPAR. 11(2): 67-73.

21. Master and $\mathrm{PhD}$ in Constitutional Law from the University of Fortaleza Professor of the State University of Piauí, Lawyer and Legal Consultant.

22. The theme will be further debated in the topic on prejudice and diffusion effects of hate speech.

23. Heller Agnes (2008) The daily life and history. Translation Carlos Nelson Coutinho and Leandro Konder. Peace and Earth, São Paulo, Brazil.

24. Brazilian society was constructed of Indians, natives of Brazilian territory, of Europeans, initially of the Portuguese after Dutch, Italian and German, and of blacks, enslaved from Africa.

25. Cunha (2011) Pombaline laws were instructions of colonization launched by the Directory of the Indians, organ that aimed to populate the newly conquered territory.

26. Ribeiro Darcy (1995) The Brazilian people: the evolution and the meaning of Brazil. Companhia das Letras, São Paulo, Brazil.

27. Ribeiro Darcy (1995) The Brazilian people: the evolution and the meaning of Brazil. São Paulo: Companhia das Letras, pp. 115

28. Ibid pp. 117.

29. Residence of the Colonel or Farmer who held the property of the slaves, including the foreman, who often at the end of his services, when he was no longer useful, was freed.

30. Miles Tshombe L (2011) The fight against slavery and racism in Ceará Translation by Denise Costa. Fortaleza: Edições Demócrito Rocha, p. 50.

31. Heller Agnes (2008) The daily life and history. Translation Carlos Nelson Coutinho and Leandro Konder. Peace and Earth, São Paulo, Brazil.

32. Difference between birth rate and mortality rate.

33. Schwarcz Lilia Moritz (1993) The spectacle of races: scientists, institutions and racial question in Brazil. São Paulo: Companhia das Letras, p. 13. 


\section{Global Journal of Archaeology \& Anthropology}

34. Bobbio Norberto (1998) Dictionary of politics. Translation Carmen C Varriale, Gaetano Lo Monaco, João Ferreira, Luís Guerreiro Pinto Caçais and Renzo Dini. Brasília: University of Brasilia, pp. 1061.

35. Schwarcz Lilia Moritz (1993) The spectacle of races: scientists, institutions and racial question in Brazil. São Paulo: Companhia das Letras, p. 62.

36. Ribeiro Darcy (1995) The Brazilian people: the evolution and the meaning of Brazil. Companhia das Letras, São Paulo, Brazil, p. 242.

37. Wolkmer Antonio Carlos, Fagundes Lucas Machado (2011) Contemporary trends of Latin American constitutionalism: Plurinational state and legal pluralism. Thinking: Journal of Legal Sciences. Fortaleza, 16: 2

38. Moreira Vânia, Maria Losada (2008) History, ethnicity and nation: the Indian and the national formation from the perspective of Caio Prado Júnior. In: American Memory, Location, n. 16(1): 63-84.

39. Ibid pp. 208.

40. What is true for the whole race is equally true for its varieties. If we were to select people who were born with a type of characteristic that we want to intensify-suppose it was one that approached for some ideal pattern of perfection-and if we compelled marriage within the boundaries of the society so selected, generation after generation there can be no doubt that, finally, the offspring would be born with the qualities we seek, as surely as if we had the reproduction of physical characteristics and not for the intellect or alienation.

41. Mai, Lilian Denise, Angerami, Emília Luigia Saporiti (2006) Negative and positive Eugenia: meanings and contradictions. Latin American Journal of Nursing. Ribeirão Preto n. 14(2): 251-258.

42. Last but not least, one can identify a third field in which the concept of "race" was ubiquitous before the eighteenth century. It is in this field that we must look in order to study some of the main elements that constituted the concept of "race" in natural history. This domain, however, was also deeply linked to the practices in the palaces. I am referring to breeding practices and especially to horse breeding The race was considered to be the object of knowledge and power Through a variety of practices, they tried to control the reproduction of the animals they had chosen in order to produce the best offspring thus obtaining a good run. Issues such as breeding and preserving the qualities of a race, therefore, were central to breeders, and in this field "a race" was primarily reduced to mere natural characteristics (which was not the case in nobility matters). Improvement and preservation of a consequently implied breed taking care of the full range of the animals' natural functions: reproduction, feeding and living conditions.

43. Mai Lilian Denise, Angerami Emília Luigia Saporiti (2006) Negative and positive Eugenia: meanings and contradictions. Latin American Journal of Nursing. Ribeirão Preto n. 14(2): 251-258.

44. Jones Trina (2000) Shades of brown: the law of skin color. Duke law journal. 49: 1487-1557.

45. Brazil (1830) Accessed on 7 jun. 2013.

46. Brazil (1890) Accessed on 7 jun. 2013.

47. Sales Junior (2009) Ronaldo Laurentino de. Race and justice: the myth of racial democracy and institutional racism in the flow of justice. Recife: Joaquim Nabuco Foundation, Massangana Publishing House, p. 22.

48. Sales Junior (2009) Ronaldo Laurentino de. Race and justice: the myth of racial democracy and institutional racism in the flow of justice. Recife: Joaquim Nabuco Foundation, Massangana Publishing House, p 39.

49. The rebels were arrested on Cobra Island in Rio de Janeiro, where they were locked in a cell inside a rock, where 16 sailors died of suffocation.
50. Ibid p. 43.

51. Guimarães Antonio, Sérgio Alfredo (2002) Classes, races and Democracy. São Paulo, Brazil, p. 87.

52. In opposition to the constituted military regime, social movements intensified and anti-racist struggle was also incorporated with the formation of the Unified Black Movement against Racial Discrimination (MNU) and the Black Group of the MDB (Brazilian Democratic Movement) (Sales Junior, 2009, p.70). Put the meaning of MDB.

53. Guimarães Antonio, Sérgio Alfredo (2002) Classes, races and Democracy. São Paulo, Brazil, pp. 138-139.

54. Ribeiro Junior João (2005) What is Nazism. São Paulo, Brazil, p. 8-9.

55. Cruz Natália dos Reis (2009) Jewish immigration in Brazil and antiSemitism in the discourse of the elites. Politics \& Society, Florianópolis n 15: 225-250.

56. Bertonha João Fábio (1997) Brazil, Italian immigrants and fascist foreign policies, 1922-1943. Brazilian Journal of International Politics, Rio de Janeiro, n. 40(2): 106-130.

57.Zanelatto João Henrique (2011) Nazism and integralism in Santa Catarina. Annals of the XXVI National Symposium on History - Anpuh. São Paulo, Brazil, p. 1

58. Ibid p. 58

59. Carneiro Maria Luiza Tucci (2001) Anti-Semitism in the Vargas Era: Ghosts of a Generation (1930-1945). Perspectiva, São Paulo, Brazil, pp. 216.

60. Cruz Natália dos Reis (2009) Jewish immigration in Brazil and antiSemitism in the discourse of the elites. Politics \& Society, Florianópolis, 15: $225-250$.

61. Ibid p. 3.

62. Lewis Antony (2011) Freedom for the ideas we hate: a biography of the First Amendment to the American Constitution. Translated by Rosana Nucci. São Paulo, Brazil, p. 189

63. Codato Adriano (2009) LEITE, Fernando. Social class. In: Almeida Heloisa Buarque de; SZWAKO, José Eduardo (Org.). Differences, equality. São Paulo: Berlendis \& Vertecchia, p. 24

64. Schwarcz Lilia Moritz (1993) The spectacle of races: scientists, institutions and racial question in Brazil. São Paulo: Companhia das Letras, pp. 112.

65. Bertonha João Fábio (1997) Brazil, Italian immigrants and fascist foreign policies, 1922-1943. Brazilian Journal of International Politics, Rio de Janeiro, 40(2): 106-130.

66. Bobbio Norberto (1998) Dictionary of politics. Translation Carmen C. Varriale, Gaetano Lo Monaco, João Ferreira, Luís Guerreiro Pinto Caçais and Renzo Dini. Brasília: University of Brasília, 1998.

67. Brazil (1988) Constitution of the Federative Republic of Brazil of 1988 Brasília, DF, Senado.

68. http://www.planalto.gov.br/ccivil 03/leis/lim/lim-16-12-1830.htm

69. Decree n. 847. It promulgates the Penal Code, dated October 11, 1890.

70. Carneiro Maria Luiza Tucci (2001) Anti-Semitism in the Vargas Era: Ghosts of a Generation (1930-1945). São Paulo: Perspectiva, Brazil.

71. Codato Adriano, Leite Fernando (2009) Social class. In: ALMEIDA, Heloisa Buarque de; SZWAKO, José Eduardo (Org.). Differences, equality. São Paulo: Berlendis \& Vertecchia, p. 22-68.

72. Cunha Elba Monique Chagas da (2011) The Pombaline legislation and the regularity of indigenous labor: topics for the freedom and social inclusion of the Indian, or a table of salvation for the Portuguese 
crown. In: Symposium Nacional De História, 36, 2011, São Paulo. Anais. Anpuh, São Paulo, Brazil.

73. Cruz Natália dos Reis (2009) Jewish immigration in Brazil and antiSemitism in the discourse of the elites. Politics \& Society, Florianópolis, 15: $225-250$.

74. Darwin Charles (2003) The Origin of Species: in the midst of natural selection or the struggle for existence in nature. Translation Paul Mosque. Lello \& Irmão e-books, Porto, Portugal.

75. Galton Francis (1865) Hereditary talent and character. Macmillan's Magazine, 12: 157-66.

76. Guimarães Antonio, Sérgio Alfredo (2002) Classes, races and Democracy. Publisher 34, São Paulo, Brazil.

77. Heller Agnes (2008) The daily life and history. Translation Carlos Nelson Coutinho and Leandro Konder. Peace and Earth, São Paulo, Brazil.

78. Jesus Carlos, Gustavo Nóbrega (2003) de. Neo-Nazism: new outfit for an old problem. Akropolis - Journal of human sciences of 11(2): 67-73.

79. Jones Trina (2000) Shades of brown: the law of skin color. Duke law journal. 49: 1487-1557.
80. Lewis Antony (2011) Freedom for the ideas we hate: a biography of the First Amendment to the American Constitution. Translated by Rosana Nucci. São Paulo, Brazil.

81. Miles Tshombe L (2011) The fight against slavery and racism in Ceará. Translation by Denise Costa. Edições Demócrito Rocha, Fortaleza, Brazil.

82. Moreira Vânia Maria Losada (2008) History, ethnicity and nation: the Indian and the national formation from the perspective of Caio Prado Júnior. In: American Memory, Buenos Aires, 16(1): 63-84.

83. Ribeiro Darcy (1995) The Brazilian people: the evolution and the meaning of Brazil. Companhia das Letras, São Paulo, Brazil.

84. Salem Helena (1995) The tribes of evil: neo-Nazism in Brazil and in the world. Current, São Paulo, Brazil.

85. Wolkmer Antonio Carlos, Fagundes Lucas Machado (2011) Contemporary trends of Latin American constitutionalism: Plurinational state and legal pluralism. Thinking: Journal of Legal Sciences. Fortaleza, 16: 2.

86. Zanelatto João Henrique (2011) Nazism and integralism in Santa Catarina. Annals of the XXVI National Symposium on History - Anpuh. São Paulo, Brazil.

\section{Your next submission with Juniper Publishers will reach you the below assets}

- Quality Editorial service

- Swift Peer Review

- Reprints availability

- E-prints Service

- Manuscript Podcast for convenient understanding

- Global attainment for your research

- Manuscript accessibility in different formats

( Pdf, E-pub, Full Text, Audio)

- Unceasing customer service

Track the below URL for one-step submission https://juniperpublishers.com/online-submission.php 